\title{
Lungnarek: sigrar og framtíðarvonir
}

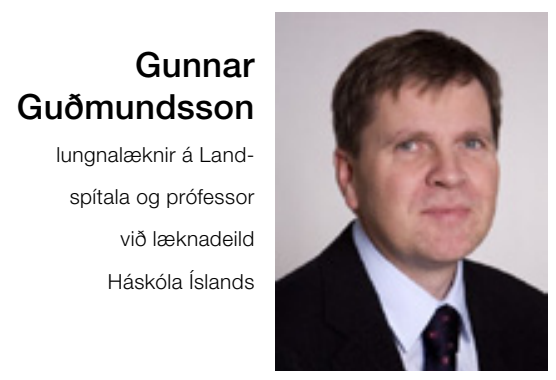

ggudmund@landspitali.is

Í pessu tölublaði Læknablaðsins birtist mjög mikilvæg grein: Lungnasegarek á Landspítala 2005-2007 - nýgengi, birtingarmynd, áhættupættir og horfur. ${ }^{1}$ Petta er afturskyggn rannsókn á inniliggjandi sjúklingum á Landspítala sem fengu sjúkdómsgreiningu um lungnasegarek á priggja ára tímabili. Petta er ein yfirgripsmesta rannsókn sem hefur birst um pennan algenga sjúkdóm á Íslandi. Hún bætir við miklum upplýsingum um nýgengi og aðra pætti. Um var að ræða yfir 300 sjúklinga og nýgengi lungnareks var 5 af hverjum 1000 sjúklingum. Prjátíu daga dánarhlutfall var 9,9\% sem undirstrikar að petta er hættulegur sjúkdómur. Petta eru miklar framfarir frá pví dánarhlutfall var um 50\% á áratugnum 1961 til 1970 og sýnir enn einn sigurinn sem náðst hefur í klínískri læknisfræði á síðustu áratugum. Greining lungnareks fer nú fyrst og fremst fram með tölvusneiðmynd af lungnaslagæðum. Hagræði er mikið miðað við ísótópaskönnun sem notuð var til greiningar áður en tölvusneiðmyndirnar komu til. Oft var erfitt að setja sjúkdómsgreininguna með vissu með peirri aðferð og erfitt að túlka niðurstöðurnar í sjúklingahópum eins og langvinnri lungnateppu. Tölvusneiðmyndirnar eru pó ekki gallalausar. Rannsóknin er sérhæfð og eingöngu gerð á fáum stöðum á Íslandi og úrlestur krefst sérfræðipekkingar og pjálfunar. Rannsóknin er kostnaðarsöm og gefið er skuggaefni og auk pess er sett umtalsverð geislun á brjóstkassann og á brjóstavef. Ýmsar vísbendingar eru um að petta sé ofnotuð rannsókn, líka hér á Íslandi, pví greiningarhlutfall er lágt. ${ }^{2}$ Kostir tölvusneiðmynda eru að pær gefa oft aðrar sjúkdómsgreiningar sem skýrt geta einkenni sjúklinga. Vanda parf val sjúklinga í pessa rannsókn.

Athygli vekur hátt hlutfall sjúklinga sem ekki hafa hina klassísku áhættupætti lungnasegareks eða tæplega fjórðungur sjúklinganna. Petta gerir sjúkdóminn vandasaman í greiningu, sérstaklega pegar tekið er tillit til pess að algengustu einkenni eru mjög ósértæk, eins og mæði, brjóstverkur, brjóstpyngsli og yfirlið. Pannig eru mismunagreiningar margar. Eitt af pví sem við purfum á að halda í framtíðinni til pess að geta bætt greiningu okkar er að finna nýja áhættupætti sem hægt er að finna með sögutöku og líkamsskoðun.

Fjöldamargar greiningaraðferðir hafa verið rannsakaðar til að meta hlutverk peirra í greiningu bráđs lungnasegareks. Á petta við bæði um nýjar og eldri rannsóknaraðferðir. Pannig hafa hvorki blóðgös né súrefnismettunarmælingar mikið vægi í greiningu. Рað sama má segja um breytingar á hjartalínuriti. Pannig sýndi rannsókn Kristjáns og félaga að hjartalínurit var óeðlilegt í 70\% tilfella en algengustu breytingarnar voru ósértækar. ${ }^{1}$ Algengustu afbrigði á hjartaómskoðun voru merki lungnaháprýstings og stækkaður slegill en 40\% voru með eðlilega hjartaómskoðun. Pá hafa röntgenmyndir af lungum ekki mikla pýðingu í greiningu en eru mikilvægar til að finna aðra skýringu á einkennum sjúklinga. Blóðrannsóknir eins og trópónín og brain natriuretic peptide hafa ekki afgerandi pýðingu í greiningu blóðsegareks. Ómskoðun á ganglimum er tímafrek rannsókn og niðurstöður háðar pjálfun pess sem framkvæmir rannsóknina. Einungis priðjungur sjúklinga með lungnasegarek er með bláæðasega við ómskoðun. Mæling á D-dimer í blóði er mikilvæg rannsókn við greiningu lungnasegareks. Рað er næmt próf sem er jákvætt hjá 95\% sjúklinga að jafnaði en fer pó eftir pví hvaða aðferð er notuð. Hins vegar er prófið ósértækt pví prófið er einungis eðlilegt í 40-68\% sjúklinga sem ekki hafa lungnasegarek. ${ }^{3}$ Best er að nota Ddimer mælingu með klínísku mati eins og breyttum Wells-kvarða til að meta líkindi á lungnasegareki. Reyndir hafa verið ýmsir aðrir kvarðar og reiknirit án pess að sýna fram á betri greiningarárangur. Hér vantar pví betri greiningarpróf og reiknirit í framtíðinni.

Léttheparín er kjörmeðferð í dag og er ýmist gefin einu sinni eða tvisvar á dag. Рað er mikil framför frá pví heparín var gefið í sídreypi með endurteknum mælingum og víst að fáir vildu hverfa aftur til peirra tíma. Miklar rannsóknir eru í gangi á nýjum blóðpynningarlyfjum og við munum sjá afraksturinn á næstu árum og erum pegar farin að sjá hann í langtímablóðpynningarmeðferð. ${ }^{4}$

Í flestum tilvikum eru sjúklingar með lungnasegarek lagðir inn á sjúkrahús að minnsta kosti fyrsta sólarhringinn. Á tímum fækkandi sjúkrarúma eru að koma fram vísbendingar um að suma sjúklinga megi senda heim af bráðadeild eftir greiningu og fyrstu meðferð. ${ }^{5}$

\section{Heimildir}

1. Jónsson KO, Agnarsson UP, Danielsen R, Porgeirsson G. Lungnasegarek á Landspítala 2005-2007 - nýgengi, birtingarmynd, áhættupættir og horfur. Læknablaðið 2013; 99: $11-5$.

2. Guðmundsson T, Guðmundsson G, Kjartansson O. Tölvusneiðmyndir af lungnaslagæðum: ofnotuð rannsókn? Læknablaðið 2006; 92: fylgirit 52: 24-5.

3. Stein PD, Hull RD, Patel KC, Olson RE, Ghali WA, Brant R, et al. D-dimer for the exclusion of of acute venous thrombosis and pulmonary embolism: a systematic review. Ann Intern Med 2004; 140: 589-602.

4. Sinauridze EI, Panteleev MA, Ataullakhanov FI. Anticoagulant therapy: basic principles, classic approaches and recent developments. Blood Coagul Fibrinolysis 2012; 23: $482-93$

5. Zondag W, Kooiman J, Klok F, Dekkers O, Huisman M. Outpatient versus inpatient treatment in patients with pulmonary embolism: a meta-analysis. Eur Respir J 2012. [Epub ahead of print]

Pulmonary embolism: victories and future hopes

Gunnar Guðmundsson Respiratory Specialist National University Hospital and Professor of Medicine University of Iceland University Hospital, Reykjavik, Iceland and Professor Faculty of Medicine University of Iceland 